\title{
Flow cytometric determination of osmotic behaviour of animal erythrocytes toward their engineering for drug delivery
}

\author{
Ivana T. Kostić ${ }^{1}$, Vesna Lj. Ilić ${ }^{2}$, Katarina M. Bukara ${ }^{1}$, Slavko B. Mojsilović ${ }^{2}$, Zorka Ž. Đurić ${ }^{3}$, \\ Petra Draškovič ${ }^{4}$, Branko M. Bugarski ${ }^{1}$ \\ ${ }^{1}$ Department of Chemical Engineering, Faculty of Technology and Metallurgy, University of Belgrade, Belgrade, Serbia \\ ${ }^{2}$ Institute for Medical Research, University of Belgrade, Belgrade, Serbia \\ ${ }^{3}$ Institute of Technical Sciences of Serbian Academy of Sciences and Arts, Belgrade, Serbia \\ ${ }^{4} B I A$, Laboratory and process equipment company Ltd., Ljubljana, Slovenia
}

\begin{abstract}
Despite the fact that the methods based on the osmotic properties of the cells are the most widely used for loading of drugs in human and animal erythrocytes, data related to the osmotic properties of erythrocytes derived from animal blood are scarce. This work was performed with an aim to investigate the possibility of use the flow cytometry as a tool for determination the osmotic behaviour of porcine and bovine erythrocytes, and thus facilitates the engineering of erythrocytes from animal blood to be drug carriers. The method of flow cytometry successfully provided the information about bovine and porcine erythrocyte osmotic fragility, and made the initial steps in assessment of erythrocyte shape in a large number of erythrocytes. Although this method is not able to confirm the swelling of porcine erythrocytes, it indicated the differences in porcine erythrocytes that had basic hematological parameters inside and outside the reference values. In order to apply/use the porcine and bovine erythrocytes as drug carriers, the method of flow cytometry, confirming the presence of osmotically different fractions of red blood cells, indicated that various amounts of the encapsulated drug in porcine and bovine erythrocytes can be expected.
\end{abstract}

Keywords: flow cytometry, osmotic swelling, osmotic fragility, mechanical fragility, microcytic anaemia, erythrocytes.

\author{
SCIENTIFIC PAPER \\ UDC 619:612.111]:66:60:615 \\ Hem. Ind. 69 (1) 67-76 (2015) \\ doi: 10.2298/HEMIND140124021K
}

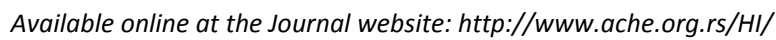

Erythrocytes are the most abundant cellular components (>99\%) of blood in humans. Besides their well known physiological functions, they serve as a natural blood compartment participating in biodistribution, metabolism and action of certain drugs [1]. On the other hand, the erythrocytes possess potential carrier capabilities and can be used for the controlled and targeted delivery of various bioactive compounds, including peptides and genetic materials [2]. Erythrocytes feature some unique advantages compared to other delivery systems, such as high biocompatibility, biodegradability, possibility of targeted drug delivery to the RES (reticuloendothelial system) organs, modification of the pharmacokinetic and pharmacodynamic parameters of the drug, etc. [3]. There are numerous reports that describe successful fabrications of engineered erythrocyte as novel carriers of various types of conventional and non-conventional drugs [4-8]. Various types of mammalian erythrocytes have been used for drug delivery, including erythrocytes of human,

Correspondence: V.Lj. Ilić, Institute for Medical Research, University of Belgrade, Dr Subotića 4, P.O. Box 39, 11129 Belgrade 102, Serbia.

E-mail: vesnai@imi.bg.ac.rs

Paper received: 24 January, 2014

Paper accepted: 20 February, 2014 mice, cattle, pigs, dogs, sheep, goats, monkeys, rats and rabbits $[2,3]$. Methods based on the osmotic properties of the cells, such are hypotonic haemolysis, hypotonic dilution, hypotonic preswelling, hypotonic dialysis, etc., are the most widely used for loading of drugs in human and animal erythrocytes [2]. However, data related to the osmotic properties of erythrocytes derived from animal blood are scarce.

Classic tests for determination the osmotic behaviour of erythrocytes, including osmotic fragility test for determination of osmotic resistance [9] and microhematocrit method for determination of osmotic swelling [10], were found to be labour intensive and time consuming. The modern sophisticated method of flow cytometry emerges as a promising method for analysis of osmotic behaviour parameters for large number of cells in short time [11], although this method is rarely used for such studies in animals. This work was performed with an aim to investigate the possibility of use the flow cytometry as a tool for determination the osmotic behaviour of porcine and bovine erythrocytes, and thus facilitate the engineering of erythrocytes from animal blood to be drug carriers. 


\section{EXPERIMENTAL}

\section{Chemicals}

The salts used in the preparation of buffers were of analytical grade and purchased from Sigma Aldrich (St. Louis, MO, USA).

\section{Blood samples and preparation of packed erythrocytes}

This study was performed by using bovine and porcine blood, acquired from slaughterhouse "PKB Imes" in Belgrade, Serbia, and collected during slaughtering. Transport and treatment of the animals in the slaughterhouse was in obedience to the National Regulation on Animal Welfare, and all studies were performed in compliance with institutional animal care and use policies.

Blood of Holstein-Friesian calves and Swedish Landrace swine was taken from jugular vein and collected in a sterile glass bottle containing $3.8 \%$ sodium-citrate as an anticoagulant agent. Blood samples were transported at ambient temperature and processing started two hours after the collection. Centrifugation of whole blood at $2450 \mathrm{~g}$ for $20 \mathrm{~min}$ at $4{ }^{\circ} \mathrm{C}$ was performed in Megafuge 1.0R, Heraus centrifuge (Langenselbold, Germany). Plasma and leucocytes (buffy coat) were carefully discarded by vacuum aspiration. The remaining pelleted erythrocytes were resuspended in isotonic $(0.9 \%, w / V)$ saline solution, washed twice via centrifugation, and finally resuspended in an isotonic phosphate buffered saline, $\mathrm{pH} 7.2-7.4$ (PBS, $0.8 \%$ saline buffered with $10 \mathrm{mM}$ sodium phosphate).

The cyanmethaemoglobin method [12] was used for determination of haemoglobin concentration in erythrocyte suspension. Haematocrit (Hct expressed as \%) was measured by the microhaematocrit method [13], while the erythrocyte were stained with Hayeam solution and counted using a Spenser haemocytometer. Haematological parameters, mean corpuscular volume (MCV), mean corpuscular haemoglobin (MCH) and mean corpuscular haemoglobin concentration (MCHC) were calculated according to the formulas proposed by Wintrobe [14].

\section{Osmotic fragility test}

The osmotic resistance of erythrocytes was determined by the method of Beutler [9]. The extent of haemolysis (EH) in each sample was expressed as a percentage of the control, where the optical density $\left(O D_{540}\right)$ of a distilled water-lysed sample of erythrocytes was set as $100 \%$. The cumulative osmotic fragility curve was plotted from the $E H$ values obtained in serial dilution of saline by Boltzmann sigmoidal function.

\section{Determination of osmotic swelling by microhaematocrit method}

The osmotic swelling index and extent of haemolysis were determined according to the methodology described by Vitvitsky et al. [10] and modified by Stojanović et al. [15].

\section{Analysis of osmotic behaviour by flow cytometry}

To analyse the osmotic behaviour of bovine and porcine erythrocytes by flow cytometry, a protocol based on determination of relative size of erythrocytes, after their incubation in series of buffer solutions with decreasing concentrations, was introduced.

In series of tubes each containing $2 \mathrm{~mL}$ of $5 \mathrm{mM}$ sodium phosphate-buffered saline with $\mathrm{NaCl}$ solution of different concentrations (range from 155 to $80 \mathrm{mM}$ ), $5 \mu \mathrm{L}$ of packed erythrocytes were added per tube. The obtained suspension was incubated at room temperature for $20 \mathrm{~min}$. The erythrocytes' size was assessed by forward scatter (FSC) analysis on CyFlow ${ }^{\circledR}$ SL flow cytometer (Partec, Münster, Germany) using FlowMax 2.4 software (Partec, Münster, Germany). At least 60000 up to maximum 100000 events per sample were analysed using $0.1 \mu \mathrm{L} / \mathrm{s}$ flow rate. Under this condition acquisition speed was approximately 7000 events/s. The intensity of forward scatter (FSC) from each individual event was detected and assigned to one of 256, 512 or 1024 quantity classes, and presented in FSC/SSC dot plots as relative values in 3 decades logarithmic scale or in FSC/Events counts histograms in linear scale.

In order to evaluate the erythrocyte osmotic behaviour, the technique described by Piagnerelli et al. [16] was modified and expanded using the FSC signal in isotonic, as well as in hypotonic conditions.

\section{Mechanical fragility test}

Suspension of packed erythrocytes was prepared in PBS to approximate value of haematocrit $40 \%$. Packed erythrocytes' suspension was added in each of five marked test tubes in volume of $5 \mathrm{~mL}$. Three of them contained nothing but erythrocytes, and two of them additionally contained glass balls. One of the test tubes with and one without glass balls were placed in horizontal shaker with $320 \mathrm{rpm}$, and erythrocytes were exposed to mechanical force during $90 \mathrm{~min}$. After the exposure to mechanical force (rocking), erythrocytes were centrifuged (20 $\mathrm{min}, 2465 \mathrm{~g}$ ), and the obtained supernatant was used for measuring the $O D_{540}$. Erythrocytes' pellet from the test tube which contained erythrocytes without balls and without exposing to mechanical force was overwhelmed with distilled water. After lysis (few minutes later) and centrifugation the obtained haemolysate was used for measuring the $O D_{540}$. The mechanical fragility index $(M F I)$ in percentage was obtained according to the pattern described by Kameneva and Antaki [17]: 


$$
\operatorname{MFI}(\%)=\frac{O D_{540 \text { tube with mechanical stress }}-O D_{540 \text { tube without mechanical stress }}}{O D_{540 \text { tube with hemolysate in water }}-O D_{540 \text { tube without mechanical stress }}}
$$

\section{RESULTS AND DISCUSSION}

Red blood cells from mammals differ in many properties (cell diameter, volume and shape, membrane lipid composition, composition and organization of transmembrane and cytoskeleton protein, enzyme activity, ionic composition, ATP and other metabolite contents,...) $[18,19]$, and each of them has less or more impact on osmotic behaviour. In this work, osmotic resistance of bovine and porcine erythrocytes was analysed by standard osmotic fragility test. All examined samples had basic erythrocytes indices in the reference range: $M C V$ 40-55 and $53-54 \times 10^{-15} \mathrm{~L} ; \mathrm{MCH} 11-17$ and 17-21 pg; and MCHC 300-322 and 300-322 g/L, for bovine and porcine erythrocytes, respectively. The osmotic fragility curves obtained by plotting the extent of haemolysis against $\mathrm{NaCl}$ concentration were of a sigmoidal shape (Figure 1). Porcine erythrocytes were more osmotically fragile then bovine ones. The literature data regarding osmotic properties of animal erythrocytes are limited and differ, even opposite reports have been published. Cardoso and Camargos [20] claimed that porcine and human erythrocyte membranes possessed similar rheological properties. On the other hand, the articles published by Matsuzawa and Ikarashi [21], Brzezińska-Slebodzińska [22] and Johnstone and co-workers [23] are in agreement with our findings which show that bovine erythrocytes exhibit higher resistance to osmotic lysis than porcine erythrocytes.

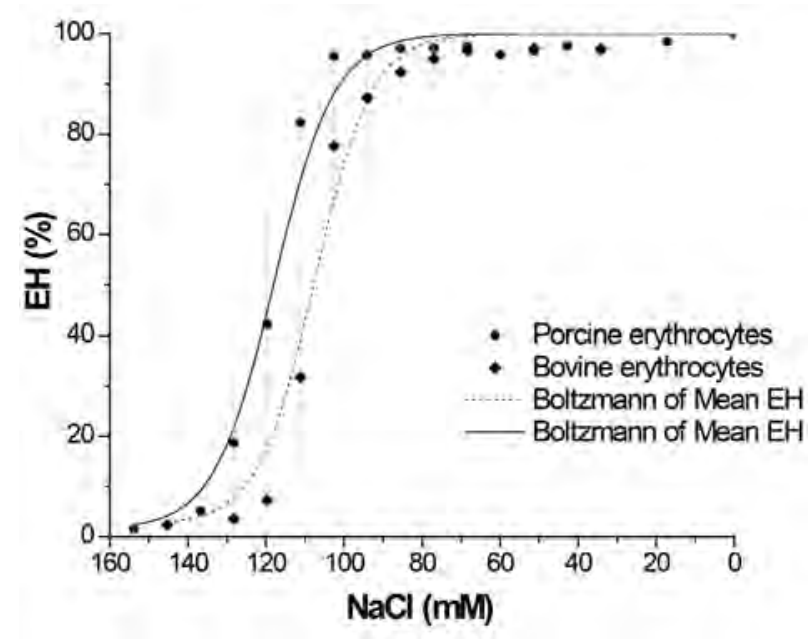

Figure 1. Mean cumulative osmotic fragility curves of bovine and porcine erythrocytes. Points - mean values of four samples; vertical bar-standard deviation; lines - fitting curves.

Parallel with the classical osmotic fragility test it was performed the mechanical fragility (MF) test, as a reliable and reproducible method of applying shear stress to erythrocytes. The output of the MF test is the Mechanical Fragility Index $(M F I)$. Higher $M F I$ values indicate that erythrocytes are more predisposed to lysis when exposed to shear stress. Both sets of the examined erythrocytes revealed similar low extent of mechanically induced haemolysis, as shown in Figure 2.

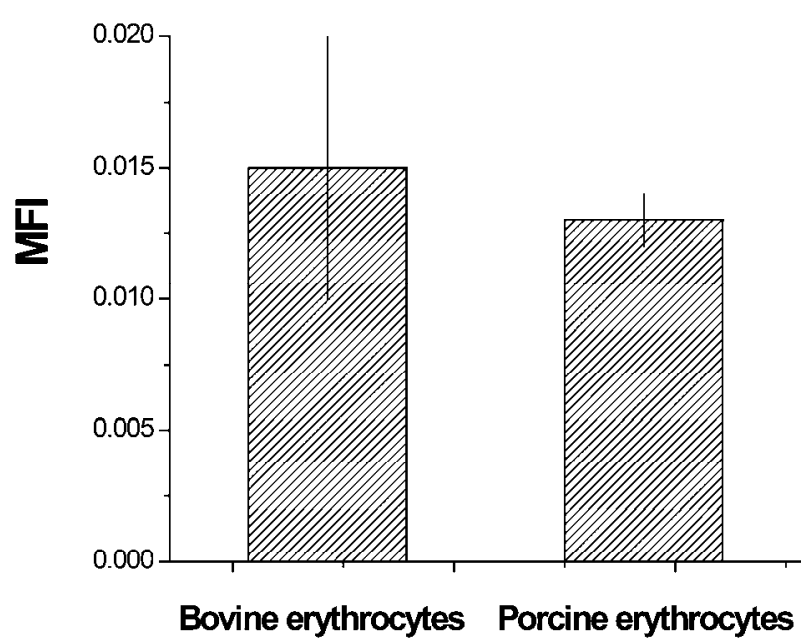

Figure 2. Mechanical fragility indexes (MFI) of bovine and porcine erythrocytes. Results are presented as mean $\pm S D$ values of three experiments.

Flow cytometric analyses were performed on erythrocytes incubated in the same buffer solutions which had been used for classic test of osmotic fragility. As depicted in FSC/SSC diagram in Figure 3 (a1 and b1), flow cytometer viewed the flow of both kinds of the examined erythrocytes in isotonic buffer solution as essentially two populations of cells. That phenomenon occurs due to biconcave shape of erythrocytes, and has been reported for human and mice erythrocytes $[16,24,25]$, thus we fixed two gates of interest for these diagrams: R1 and R2. As presented in Figure 3 (a-2, b-2, $a-3$ and $b-3)$, with decrease of buffer concentration from 155 to $65 \mathrm{mM}$ one other population of small "events" (population R5) became visible. Most probably, the population of small vesicles was developed due to fragmentation of mechanically impaired swelled cells caused by shear flow in flow cytometer. This population of small vesicles enlarged with the decrease of buffer concentration down from $94 \mathrm{mM}$, and in the case of porcine erythrocytes at buffer concentration of $80 \mathrm{mM}$ became predominant. In the case of bovine erythrocytes, FSC/SSC diagram obtained in buffer concentration of $65 \mathrm{mM}$ (Figure 3, a-3) revealed solely the presence of those small vesicles. This result was in accordance with the previous finding obtained by osmo- 
a

\section{1}

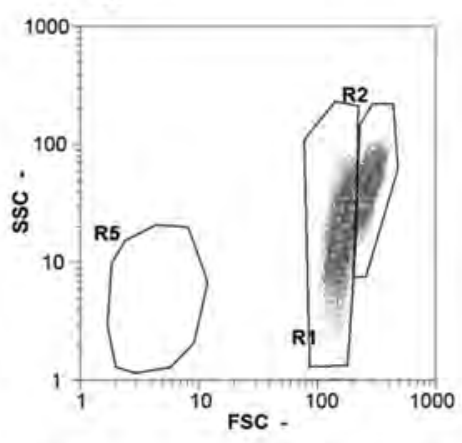

2

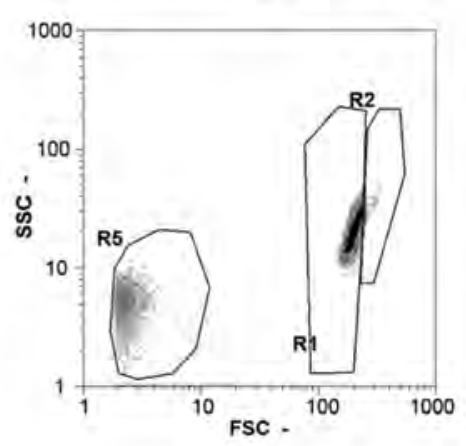

3
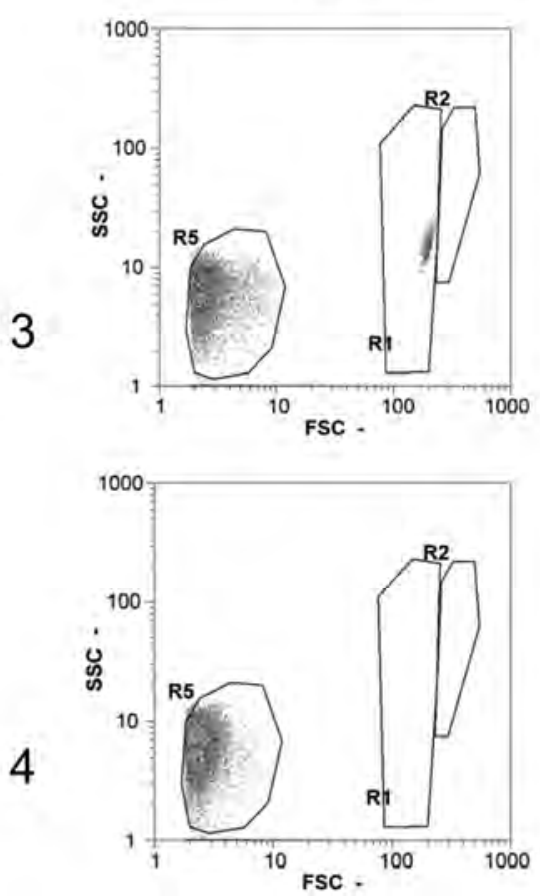

b
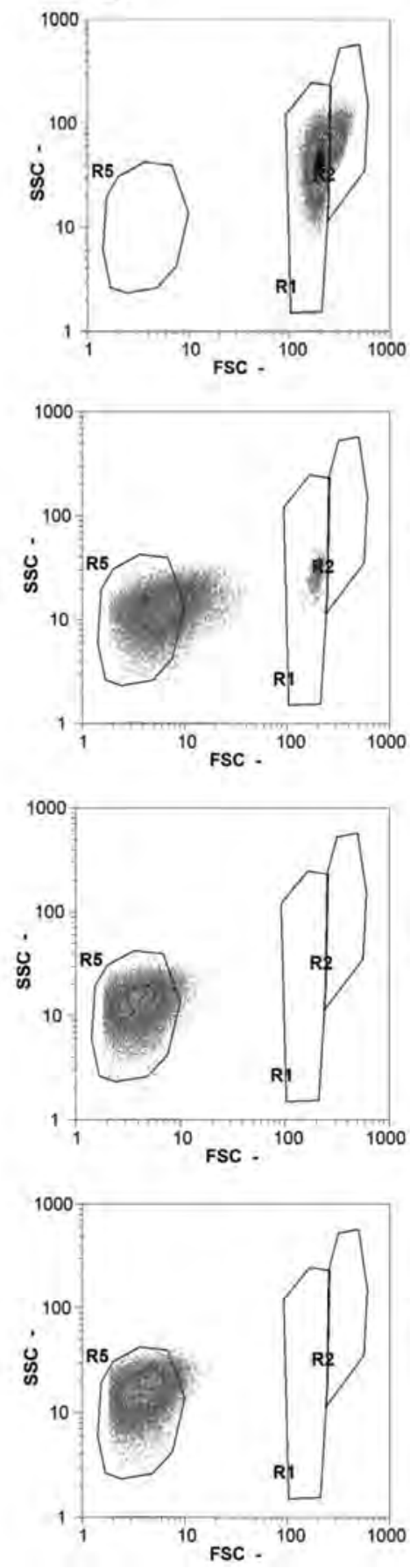

$155 \mathrm{mM}$

$94 \mathrm{mM}$

$80 \mathrm{mM}$

$65 \mathrm{mM}$

Figure 3. Flow cytometric analysis (FSC/SSC diagrams) of bovine (a) and porcine (b) erythrocytes exposed to hypotonic sodiumphosphate/NaCl buffers of decreasing concentrations. R1, R2 - erythrocyte populations, $R 5$ - small vesicles.

tic fragility test that porcine erythrocytes were more osmotically fragile compared to bovine ones. Although the mechanical stress caused by shear flow in flow cytometer could not be neglected, the demonstrated equal MFI for bovine and porcine erythrocytes indicated that the obtained differences in FSC/SSC diagrams of erythrocytes incubated in same hypotonic buffer really reflected their different osmotic properties.
Regardless of the pronounced vesiculation, it was possible to analyse erythrocytes swelling by flow cytometry in $139 \mathrm{mM}$ buffer, and buffers with lower concentration. FSC/counts histograms obtained for 2 samples of each bovine and porcine erythrocytes (Figures 4 and 5) in isotonic buffer solution (155 mM), because of their biconcave shape, showed bimodal size distribution (as represented by gates R1 and R2 in Fig- 


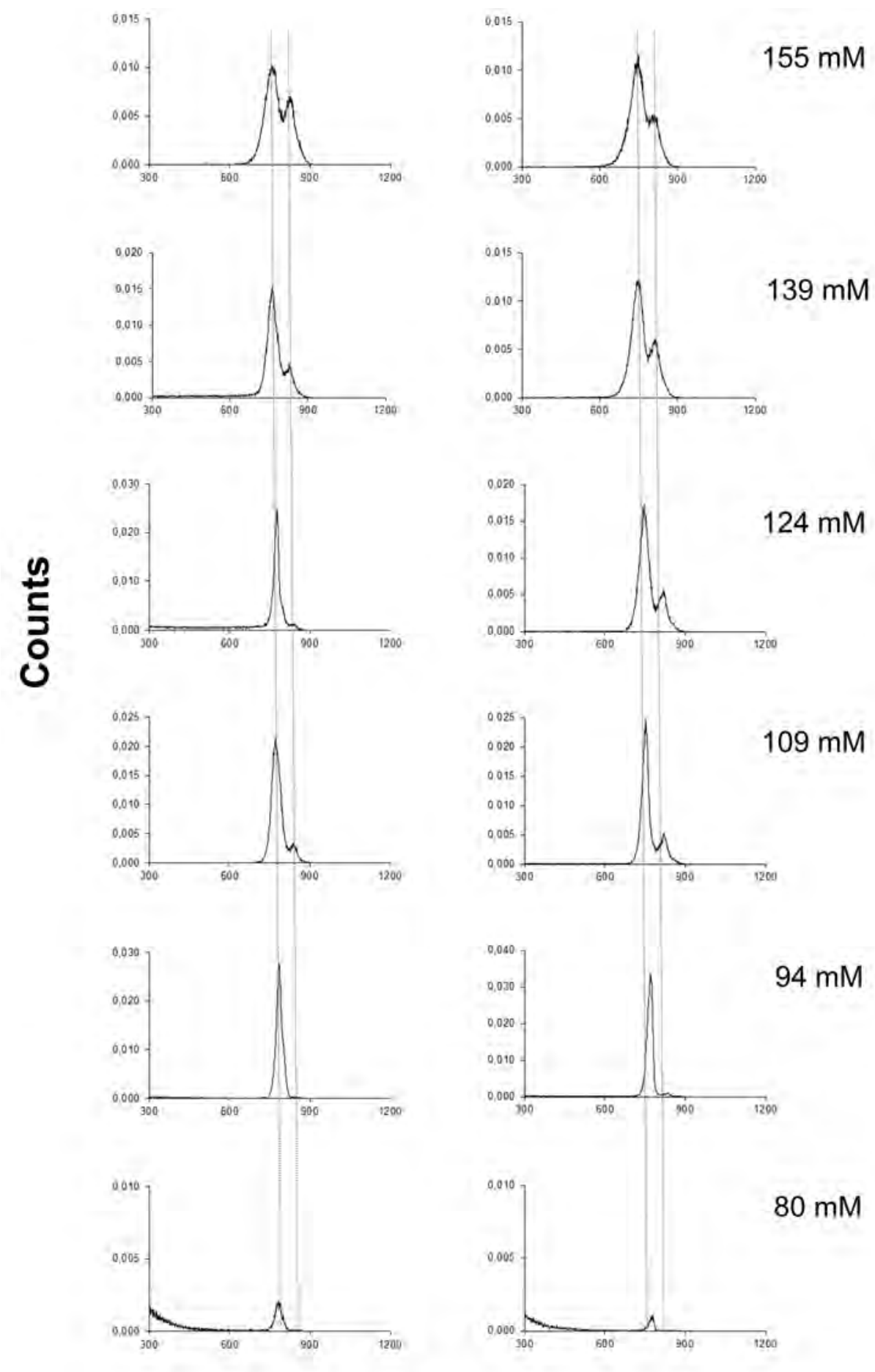

\section{FCS}

Figure 4. Changes in FSC values of bovine erythrocytes with decreasing concentration of sodium-phosphate/NaCl buffers.

ure 3). It is evident that bovine erythrocytes are smaller than porcine cells (reflected in minor FSC values), as also reported by other authors [26]. The hypotonic buffers were used with an aim to promote swelling and gave spherical shape of erythrocytes, thus eliminating variations in FSC caused by biconcave shape, as pro- posed by van den Bos [25]). As depicted in Figure 4, two representative samples of bovine erythrocytes with basic parameters within reference range revealed uniform pattern after exposing to hypotonic solutions. In the case of bovine erythrocytes, alterations in shape of the resulting $\mathrm{FSC} /$ counts histogram in corresponding 

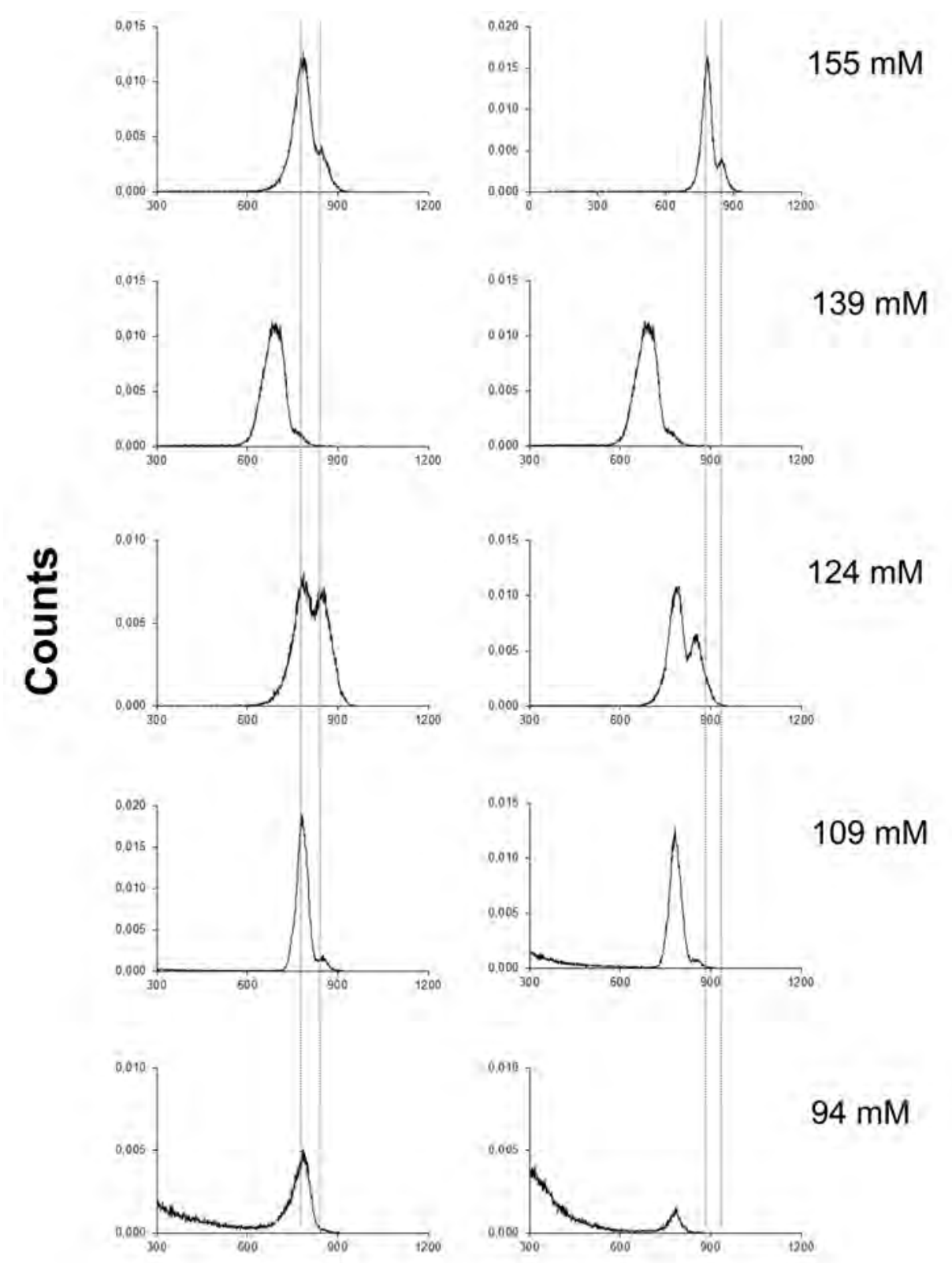

\section{FCS}

Figure 5. Changes in FSC values of porcine erythrocytes with decreasing concentration of sodium-phosphate/NaCl buffers.

hypotonic buffer reflected changes in erythrocyte osmotic properties, from swelling to fragmentation to small vesicles in $80 \mathrm{mM}$.

In the case of porcine erythrocytes, two samples from apparently healthy pigs with erythrocytes indices within reference range (Figure 5) did not reveal uniform FSC/counts pattern. Moreover, the resulting FSC/ /counts histograms in corresponding hypotonic buffers did not reveal swelling. The fragmentation of porcine erythrocytes has already been detected in $109 \mathrm{mM}$ buffer, confirming once more their increased osmotic fragility compared to bovine erythrocytes. This finding about more osmotically fragile porcine erythrocytes was opposite to the reports of Jain [26], who declared that there was a linear relationship between cell size and osmotic resistance. Thus, smaller bovine erythrocytes (with minor FSC values) are expected to be less osmotic resistant than larger porcine ones (with higher FSC values), but results obtained by flow cytometry showed the opposite.

Furthermore, from this study we postulated the existence of osmotically different fractions of erythrocytes derived from bovine and porcine blood. Obviously, the fractions were different in size (as bimodal 
size distribution in hypotonic buffer was confirmed by flow cytometry) and in swelling ability. As far as we know, bimodal distribution of size detected by flowcytometry is typical for biconcave cells, such are the erythrocytes, as long as they are in the isotonic suspension [25], while this is not a case for cells which suffered from shape distortion to spheres upon treatment with a hypotonic solution. Thus, different loaded amount of drug in individual erythrocyte derived from both porcine and bovine blood could be expected, as it was reported for human erythrocyte [27].

Besides samples which had normal erythrocytes indices, one of the examined samples of porcine erythrocytes had $M C V\left(42 \times 10^{-15} \mathrm{~L}\right)$ and $\mathrm{MCH}(15 \mathrm{pg})$ values lower than the reference ones, indicating to a potential disorder of microcytic hypochromic anaemia [28]. FSC/ /counts histograms of that sample of porcine erythrocytes incubated in isotonic and hypotonic buffers (Figure 6) exposed FSC/counts patterns different from

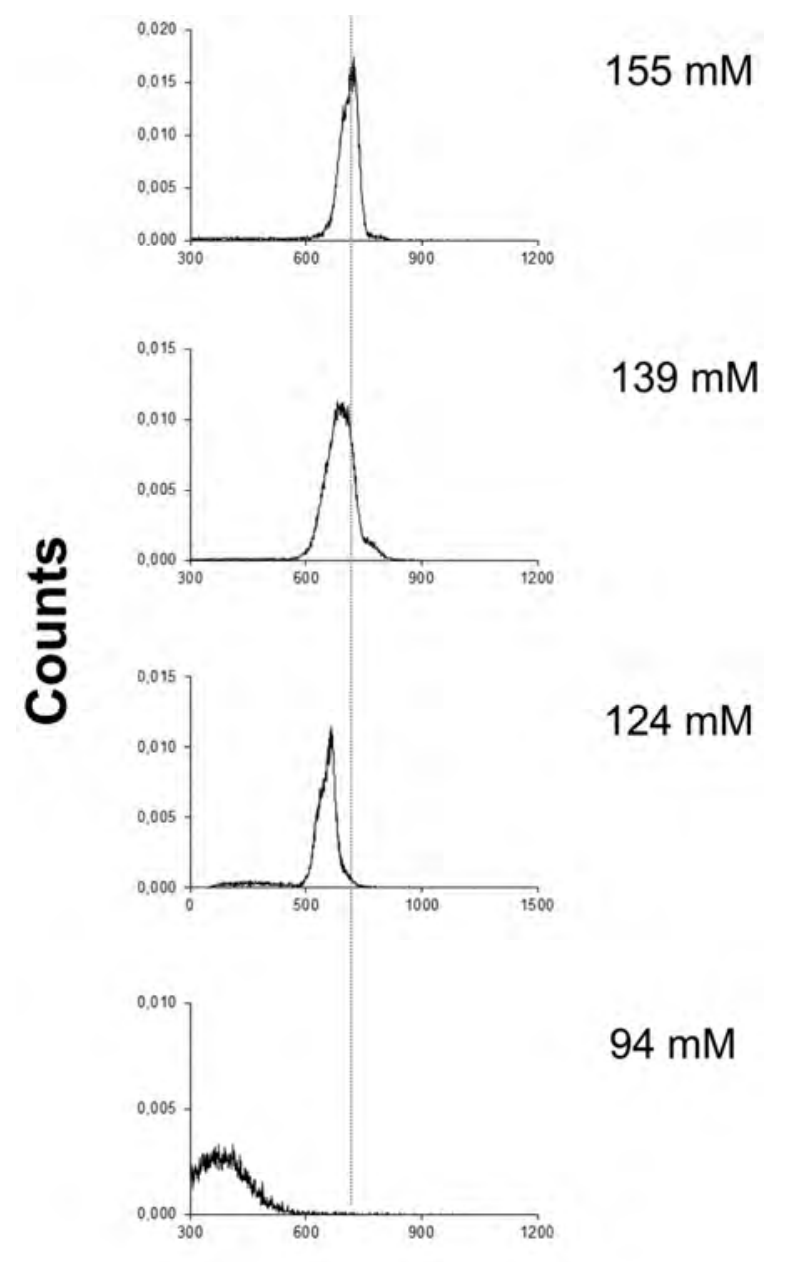

\section{FCS}

Figure 6. Changes in FSC values of "microcytic" porcine erythrocytes with decreasing concentration of sodiumphosphate/ $\mathrm{NaCl}$ buffers. those of apparently healthy samples of porcine erythrocytes, with decreased FCS values and changed shape of the FCS/counts curve (Figure 5). Since the flow cytometry technique has already been successfully described for assessment of erythrocytes shape in isotonic conditions in different pathologies [16], we compared the samples of apparently healthy bovine and porcine erythrocytes, as well as sample of porcine erythrocytes having basic erythrocyte parameters without reference range. As described by Piagnerelli et al. [16], the calculated spherical indexes amounted to $1.58 \pm 0.08$ and $1.67 \pm 0.08$, respectively, for the samples of porcine and bovine erythrocytes, while the potentially pathological sample of porcine erythrocytes gave the index of 1.45. The obtained minor index in the case of porcine erythrocyte sample with potential microcytic anaemia was in accordance with reports of human spherocytes which possess increased osmotic fragility [29].

Furthermore, we extended the procedure for shape assessment described by Piagnerelli et al. [16], and compared the mentioned indexes of the determined gates R1 and R2, obtained in hypotonic solutions, with results of osmotic swelling obtained from more routinely used microhematocrit test. In the mentioned comparison, the index obtained in isotonic solution was taken as a unit value. The correlations of the results are shown in Figure $7 a$ and $b$, for bovine and porcine erythrocytes, respectively. The swelling index obtained by microhematocrit method was strongly correlated with the indexes obtained by flow cytometry in the case of bovine erythrocytes, Hct: R2/R1 $=0.84, p=0.036$, Hct: $\mathrm{R} 1 / \mathrm{R} 1=0.95, p=0.0034, \mathrm{Hct}: \mathrm{R} 2 / \mathrm{R} 2=0.83, p=0.039$ $(p<0.05)$, as shown in Figure 7a. In the sample of porcine erythrocytes, there was no significant correlation between the swelling index calculated by microhematocrit method and indexes obtained by flow cytometry (Figure 7b).

\section{CONCLUSION}

The flow cytometry technique seemed to be a rapid technique, easier than the conventional methods for determination of osmotic behaviour of erythrocytes. By the use of this technique we successfully provided the information about bovine and porcine erythrocyte osmotic fragility, and made initial steps in assessment of erythrocyte shape in a large number of erythrocytes. Nevertheless, this technique could not provide confirmation of swelling of porcine erythrocytes, but indicated the difference in samples of porcine erythrocytes within and without range of basic haematological parameters. Toward use of bovine and porcine erythrocytes as drug carriers, the demonstrated existence of osmotically different fractions of erythrocytes indicated that different loaded amount of drug in individual erythrocyte derived from both porcine and bovine blood can 

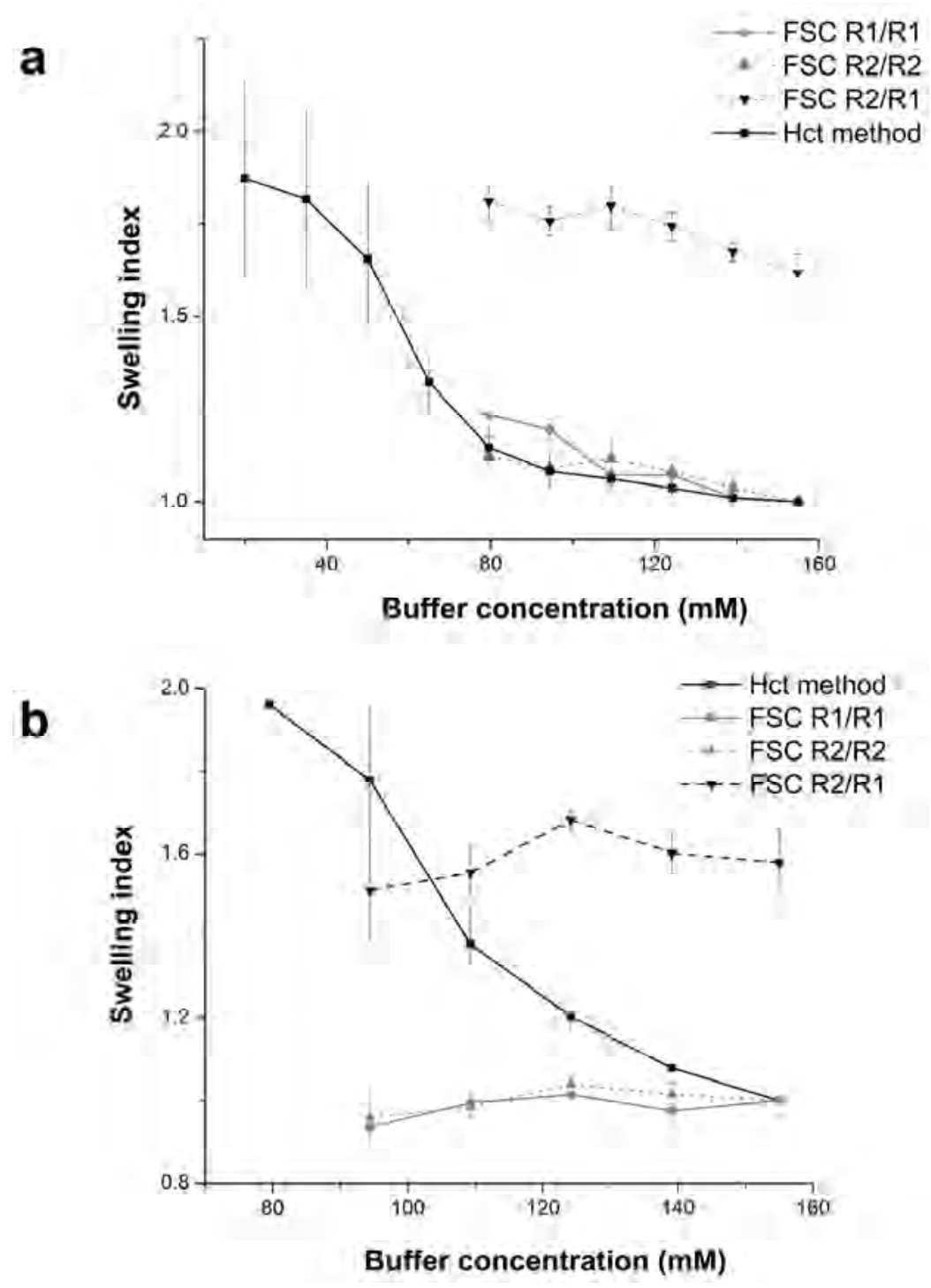

Figure 7. The swelling index of bovine (a) and porcine (b) erythrocytes determined by microhematocrit method, as described by Stojanović et al. (2012) (results are presented as mean \pm SD values of five experiments) and by flow cytometry (results are presented as mean $\pm S D$ values of three experiments).

be expected. With an aim to define more in depth the osmotic and related rheological properties of different mammalian erythrocytes, application of flow cytometry technique merits further investigation.

\section{Acknowledgement}

This research was supported by Ministry of Education, Science and Technological Development, Republic of Serbia (project III46010) and Ministry of Education, Science and Sport, Republic of Slovenia (Serbia-Slovenia science and technology cooperation for years 2012-2013). The authors thank to Novak Kovačević, DVM, for having kindly provided us blood samples from the slaughterhouse PKB "Imes", Belgrade, Serbia.

\section{REFERENCES}

[1] P.H. Hinderling, Red Blood Cells: A Neglected Compartment in Pharmacokinetics and Pharmacodynamics, Pharmacol. Rev. 49 (1997) 279-295.

[2] M. Hamidi, A. Zarrin, M. Foroozesh, S. MohammadiSamani, Applications of carrier erythrocytes in delivery of biopharmaceuticals, J. Control. Release. 118 (2007) 145-160.

[3] V.R. Muzykantov, Drug delivery by red blood cells: vascular carriers designed by mother nature, Expert Opin. Drug Deliv. 7 (2010) 403-427.

[4] M.A. Milanick, S. Ritter, K. Meissner, Engineering erythrocytes to be erythrosensors: first steps, Blood Cells Mol. Dis. 47 (2011) 100-106.

[5] M. Foroozesh, M. Hamidi, A. Zarrin, S. MohammadiSamani, H. Montaseri, Preparation and in-vitro characterization of tramadol-loaded carrier erythrocytes for 
long-term intravenous delivery, J. Pharm. Pharmacol. 63 (2011) 322-332.

[6] M. Shaillender, R. Luo, S.S. Venkatraman, B. Neu, Layerby-layer microcapsules templated on erythrocyte ghost carriers, Int. J. Pharm. 415 (2011) 211-217.

[7] N. Sternberg, R. Georgieva, K. Duft, H. Bäumler, Surfacemodified loaded human red blood cells for targeting and delivery of drugs, J. Microencapsulation 29 (2012) 9-20.

[8] G.I. Harisa, M.F. Ibrahim, F.K. Alanazi, Erythrocyte-mediated delivery of pravastatin: in vitro study of effect of hypotonic lysis on biochemical parameters and loading efficiency, Arch. Pharmacal Res. 35 (2012) 1431-1439.

[9] E. Beutler, in: W.J. Williams, E. Beutler, A.J. Erslev, M.A. Lichtman (Eds.), Hematology, McGraw-Hill Book Co, New York, 1983, pp. 1626-1627.

[10] V.M. Vitvitsky, E.V. Frolova, M.V. Martinov, S.V. Komarova, F.I. Ataullakhanov, Anion permeability and erythrocyte swelling, Bioelectrochemistry 52 (2000) 169$-177$.

[11] D.I. Won, J.S. Suh, Flow cytometric detection of erythrocyte osmotic fragility, Cytometry B Clin. Cytom. 76 (2009) 135-141.

[12] O.W. van Assendelft, A.H. Holtz, S.M. Lewis, Recommended method for the determination of the haemoglobin content of blood, I.C.S.H. Publications World Health Organization, 1.4.1. (1984).

[13] J.C. Sabine, D.J. Nickolai, A microhaematocrit method and its use with citrated blood, Blood 7 (1952) 1128$-1131$.

[14] M.M. Wintrobe, in: M.M. Wintrobe (Ed.), Clinical Hematology, $8^{\text {th }}$ ed., Lea \& Febiger, Philadelphia, PN, 1981, pp.7-19.

[15] R. Stojanović, V. Ilić, V. Manojlović, D. Bugarski, M. Dević, B. Bugarski, Isolation of haemoglobin from bovine erythrocytes by controlled hemolysis in the membrane bioreactor, Appl. Biochem. Biotechnol. 166 (2012) 1491-1506.

[16] M. Piagnerelli, K. ZouaouiBoudjeltia, D. Brohee, A. Vereerstraeten, P. Piro, J.L. Vincent, M. Vanhaeverbeek, Assessment of erythrocyte shape by flow cytometry techniques, J. Clin. Pathol. 60 (2007) 549-554.

[17] M.V. Kameneva, J.F. Antaki, in: O.K. Baskurt (Ed.), Handbook of Hemorheology and Hemodynamics, IOS press, Amsterdam, 2007, pp. 206-227.
[18] N.C. Jain, Measurement, interpretation, factor involved, and mechanism of osmotic fragility with observation of animal erythrocytes, Bulletin of the American Society of Veterinary Clinical Pathologists 1 (1972) 3-24.

[19] J.W. Harvey, in: J.J. Kaneko, J.W. Harvey, M.L. Bruss (Eds.), Clinical Biochemistry of Domestic Animals, Academic Press, New York, 2008, pp. 173-238.

[20] A.V. Cardoso, A.O. Camargos, Geometrical aspects during formation of compact aggregates of red blood cells. Mat. Res. 5 (2002) 263-268.

[21] T. Matsuzawa, Y. Ikarashi, Hemolysis of various mammalian erythrocytes in sodium chloride, glucose and phosphate-buffer solutions, Lab. Anim. 13 (1979) 329$-331$.

[22] E. Brzezińska-Slebodzińska, Species differences in the susceptibility of erythrocytes exposed to free radicals in vitro, Vet. Res. Commun. 27 (2003) 211-217.

[23] J.E. Johnstone, L.A. MacLaren, J. Doucet, V.C. McAlister, In vitro studies regarding the feasibility of bovine erythrocyte xenotransfusion, Xenotransplantation $\mathbf{1 1}$ (2004) 11-17.

[24] K.A. Gutowski, J.L. Hudson, D. Aminof, Flow cytometric analysis of human erythrocytes: I. probed with lectins and immunoglobulins, Exp. Gerontol. 26 (1991) 315$-326$.

[25] C. van den Bos, F.C. van Gils, R.W. Bartstra, G. Wagemaker, Flow cytometric analysis of peripheral blood erythrocyte chimerism in $\alpha$-thalassemic mice, Cytometry 13 (1992) 659-662.

[26] N.C. Jain, Essential of veterinary hematology, Lea \& Febiger, Philadelphia, PN, 1993.

[27] N. Sternberg, R. Georgieva, K. Duft, H. Bäumler, Surfacemodified loaded human red blood cells for targeting and delivery of drugs, J. Microencapsulation 29 (2012) 9-20.

[28] H. Tvedten, in: J.D. Weiss, K.J. Wardrop (Eds.), Schalm's Veterinary Hematology, $6^{\text {th }}$ ed., Blackwell Publishing Ltd., Ames, 2010, pp. 152-161.

[29] R. Paleari, A. Mosca, Controversies on the osmotic fragility test, Enerca (The European network aimed at improving the diagnosis, epidemiological knowledge and medical education on rare and congenital anaemia), News (2008) 1-3. 


\section{IZVOD}

\section{ODREĐIVANJE OSMOTSKIH OSOBINA ŽIVOTINJSKIH ERITROCITA PROTOČNOM CITOMETRIJOM U CILU NJIHOVOG INŽENJERINGA KAO NOSAČA LEKOVA}

Ivana T. Kostić ${ }^{1}$, Vesna Lj. Ilić ${ }^{2}$, Katarina M. Bukara ${ }^{1}$, Slavko B. Mojsilović ${ }^{2}$, Zorka Ž. Đurić ${ }^{3}$, Petra Draškovič ${ }^{4}$, Branko M. Bugarski ${ }^{1}$

${ }^{1}$ Katedra za hemijsko inženjerstvo, Tehnološko-metalurški fakultet, Univerzitet u Beogradu, Karnegijeva 4, 11060 Beograd, Srbija

${ }^{2}$ Institut za medicinska istraživanja, Univerzitet u Beogradu, Dr Subotića 4, p. pr. 39, Beograd 102, Srbija

${ }^{3}$ Institut tehničkih nauka Srpske akademije nauka i umetnosti, Knez Mihailova 35/IV, p. pr. 377, 11129 Beograd, Srbija

${ }^{4} B I A$, Laboratory and process equipment company Ltd., Teslova 30, Ljubljana, Slovenia

(Naučni rad)

Uprkos činjenici da su metode koje se baziraju na osmotskim osobinama ćelija najčešće korišćene metode za inkapsulaciju lekova u humane i životinjske eritrocite, podaci o osmotskim osobinama eritrocita životinjskog porekla su vrlo oskudni. Cilj ovog rada bio je ispitivanje mogućnosti korišćenja metode protočne citometrije za određivanje osmotskih osobina svinjskih i goveđih eritrocita, čime bi se olakšao inženjering pomenutih životinjskih eritrocita za otpuštanje lekova. Metodom protočne citometrije uspešno su dobijene informacije o osmotskoj fragilnosti svinjskih i goveđih eritrocita i načinjeni su početni koraci u proceni oblika velikog broja eritrocita. lako ova metoda nije uspela da potvrdi bubrenje svinjskih eritrocita, ukazala je na razliku u uzorcima svinjskih eritrocita koji su imali osnovne hematološke parametre izvan i unutar referentnih vrednosti. U cilju primene svinjskih i goveđih eritrocita kao nosača lekova, metoda protočne citometrije je, potvrdivši prisustvo osmotski različitih frakcija eritrocita, ukazala na to da se različite količine inkapsuliranog leka u pojedinačnim, kako svinjskim, tako i goveđim eritrocitima mogu očekivati.
Ključne reči: Protočna citometrija • Osmotsko bubrenje • Osmotska fragilnost • Mehanička fragilnost • Mikrocitna anemija • Eritrociti 